\title{
Chapter 7 \\ Investigation of Radiocesium Translation from Contaminated Sediment to Benthic Organisms
}

\author{
Yuya Shigenobu, Daisuke Ambe, Hideki Kaeriyama, Tadahiro Sohtome, \\ Takuji Mizuno, Yuichi Koshiishi, Shintaro Yamasaki, and Tsuneo Ono
}

\begin{abstract}
We estimated the radiocesium translation from contaminated sediments to benthic organisms off the coast of Fukushima. We conducted field investigations and an experiment with a benthic polychaete (Perinereis aibuhitensis) reared on highly contaminated sediments collected from a station $1 \mathrm{~km}$ off the Fukushima Dai-ichi Nuclear Power Plant. Results of the field investigations revealed that radiocesium contamination in benthic organisms depended on their feeding habitat. The radiocesium concentration in carnivore or herbivore feeder polychaetes was higher than that in deposit feeders. Radiocesium concentrations of all benthic organism specimens were lower than that in sediments collected from the same sampling point. Results of the rearing experiment showed that the concentration ratio (CR) of ${ }^{137} \mathrm{Cs}$ for P. aibuhitensis and contaminated sediments (wet/wet) was less than 0.10 . Moreover, 4 days after separation from the contaminated sediments, the ${ }^{137} \mathrm{Cs}$ concentrations in $P$. aibuhitensis rapidly decreased. Based on the results of our field investigations and rearing experiment, we conclude that the intake of radiocesium through the benthic food web is limited for benthic organisms, despite the high contamination of the surrounding sediments.
\end{abstract}

\footnotetext{
Y. Shigenobu $(\square) \bullet$ D. Ambe $\bullet$ H. Kaeriyama $\bullet$ Y. Koshiishi $\bullet$ T. Ono National Research Institute of Fisheries Sciences, Fisheries Research Agency, 2-12-4, Fukuura, Kanazawa, Yokohama, Kanagawa 236-8648, Japan e-mail: yshig@affrc.go.jp

T. Sohtome $\bullet$ T. Mizuno

Fukushima Prefectural Fisheries Experimental Station, 13-2, Matsushita, Onahama, Iwaki, Fukushima 970-0316, Japan

S. Yamasaki

National Research Institute of Fisheries Engineering, Fisheries Research Agency, 7620-7, Hasaki, Kamisu, Ibaraki 314-0408, Japan
} 
Keywords Benthic organisms • Contaminated sediment • Rearing experiment • Concentration ratio $(\mathrm{CR})$

\subsection{Introduction}

The Fukushima Dai-ichi Nuclear Power Plant (FNPP) accident in March 2011 released a large amount of anthropogenic radionuclides into the marine environment. Although most of the short-lived radionuclides soon decayed to a level below the detection limit, two isotopes of radiocesium $\left({ }^{134} \mathrm{Cs}\right.$ and $\left.{ }^{137} \mathrm{Cs}\right)$, which have relatively long half-lives (2.07 years and 30.1 years, respectively), have been continually detected in the environment. Tsumune et al. (2012) estimated that $3.5 \pm 0.7 \times 10^{15} \mathrm{~Bq}$ of ${ }^{137} \mathrm{Cs}$ was released directly into the ocean from 26 March 2011 to the end of May 2011. The discharged radiocesium from the FNPP gradually associated with suspended material and settled to the sea bottom around Fukushima. Ambe et al. (2014) reported that the radiocesium concentrations in the surface sediment layer $(0-1 \mathrm{~cm})$ collected off the coast of Fukushima in 2012 and 2013 were mainly in the range of dozens to several hundred Bq/kg-dry (see Sect. 2.1). Moreover, the particularly highly contaminated $\left({ }^{137} \mathrm{Cs}\right.$ concentration $=40,152 \pm 3,998 \mathrm{~Bq} / \mathrm{kg}$-wet) area that is extremely small, encompassing only a few square meters of the seafloor, was confirmed near the FNPP in February 2013 (Thornton et al. 2013). It is thought that demersal fish and benthic organisms take in radiocesium from highly contaminated sediments through the benthic food web (Buesseler 2012; Tateda et al. 2013; Sohtome et al. 2014). High radiocesium concentrations were detected from some sedentary demersal fish species, such as fat greenling (Hexagrammos otakii), marbled flounder (Pseudopleuronectes yokohamae), slime flounder (Microstomus achne), and Japanese rockfish (Sebastes cheni), off the coast of Fukushima (Wada et al. 2013).

The radiocesium concentrations in benthic organisms off the coast of Fukushima range from several to dozens $\mathrm{Bq} / \mathrm{kg}$-wet (Sohtome et al. 2014). According to a previous experimental study on the concentration ratio $(\mathrm{CR})$ of ${ }^{137} \mathrm{Cs}$ between contaminated sediments and marine polychaetes $(C R=0.179)$ (Ueda et al. 1977), this level of contamination in benthic organisms off the coast of Fukushima is reasonable. However, the current transfer efficiency of radiocesium from contaminated sediments to the benthic organisms along the sea bottom off the coast of Fukushima is unclear. In this section, we discuss the results of our measurements of radiocesium concentrations in benthic organisms caught off the coast of Fukushima in October 2013 and the results of experiments rearing a benthic polychaete (Perinereis aibuhitensis) on highly contaminated sediments collected at the station $1 \mathrm{~km}$ off the FNPP in August 2013 (Fig. 7.1). Through our field investigations and the rearing experiment, we estimated the radiocesium translation from contaminated sediments to benthic organisms off the coast of Fukushima. 
Fig. 7.1 Sampling point (black spot) of benthic organisms off the coast of Fukushima in October 2013. Gray circle indicates a $20-\mathrm{km}$ radius around the Fukushima Dai-ichi Nuclear Power Plant

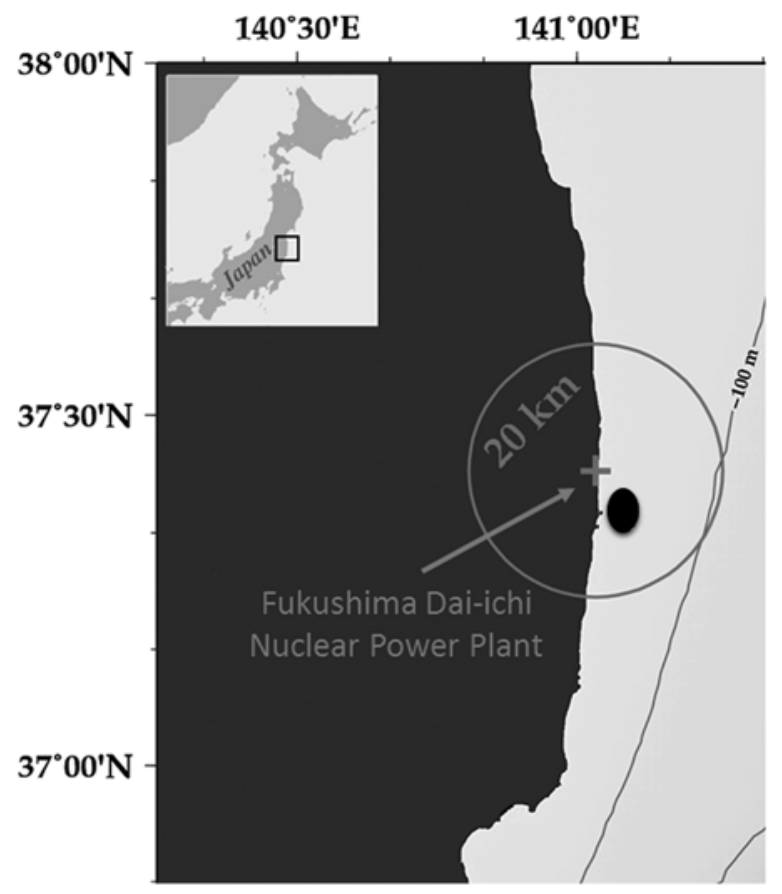

\subsection{Radiocesium Concentrations in Benthic Organisms off the Coast of Fukushima}

Benthic organisms in the southern coastal waters of Fukushima were collected using a dredge on the R/V Taka-maru of the Fisheries Research Institute of Fisheries Engineering in October 2013 (Fig. 7.1). We sorted benthic organisms into major taxonomic groups and measured radiocesium concentrations of whole-body specimens, which included digestive system contents (Fig. 7.2). The specimens were packed tightly in plastic cylindrical containers, and specific gamma rays of ${ }^{134} \mathrm{Cs}(605$ and $796 \mathrm{keV})$ and ${ }^{137} \mathrm{Cs}(662 \mathrm{keV})$ were measured with a high-purity germanium (HPGe) semiconductor detector (ORTEC, GEM30-70-LB-C, 1.85 Kev/1.33 MeV of resolution) with a multichannel analyzer.

Radiocesium concentrations in all benthic organisms were lower than that in the sediments $(216 \mathrm{~Bq} / \mathrm{kg}$-wet) collected from the same sampling point. Radiocesium concentrations in benthic organisms ranged from not-detected (N.D.) to 99.4 Bq/ $\mathrm{kg}$-wet. Although a low level of radiocesium contamination was detected in crustacean specimens, radiocesium concentrations in polychaete specimens varied among taxonomic groups (Table 7.1).

The radiocesium concentrations in benthic organisms were typically measured for whole-body specimens, which contained the contaminated sediments within and 

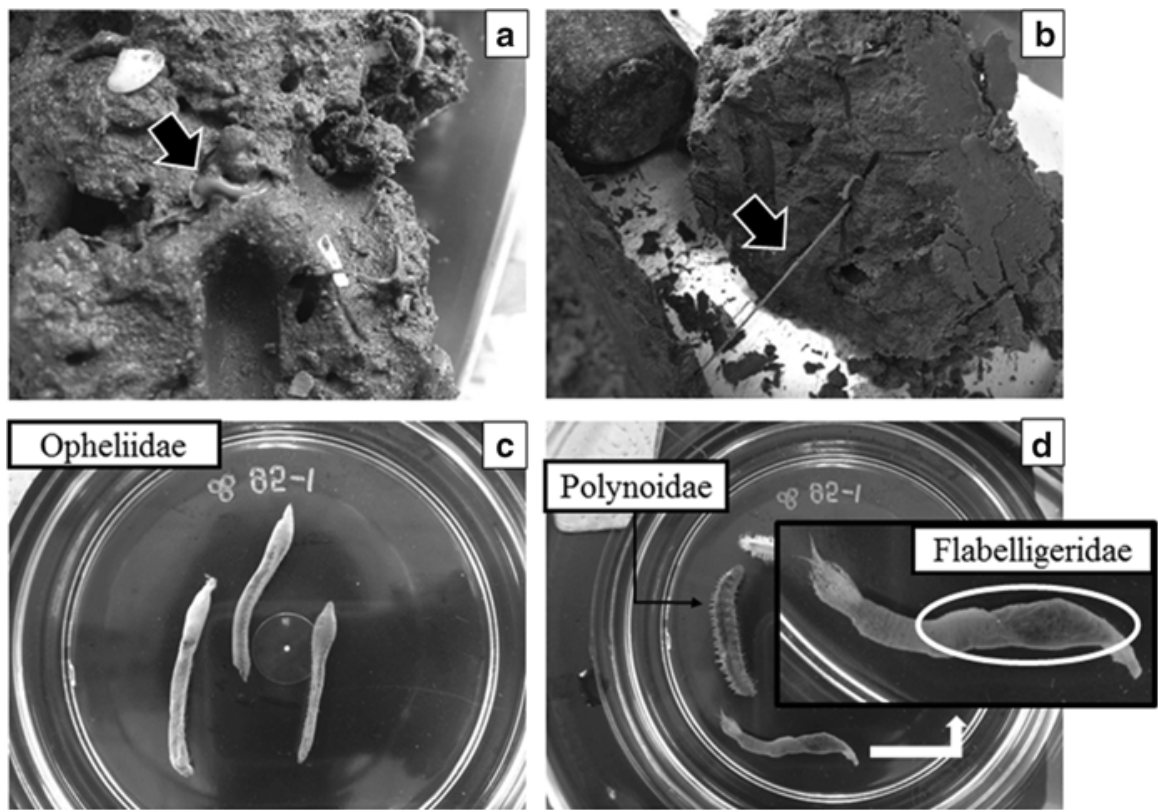

Fig. 7.2 Polychaetes collected off the coast of Fukushima in October 2013. We selected several species of polychaetes from sea sediments $(\mathbf{a}, \mathbf{b}$ and $\mathbf{c})$. White oval in $\mathbf{d}$ indicates the internal sediments in Flabelligeridae specimens

Table 7.1 Radiocesium concentrations in benthic organisms off the coast of Fukushima in October 2013

\begin{tabular}{l|l|l|l}
\hline \multirow{2}{*}{$\begin{array}{l}\text { Taxonomic group } \\
\text { of benthic organisms }\end{array}$} & $\begin{array}{l}{ }^{134} \mathrm{Cs}+{ }^{137} \mathrm{Cs} \\
\text { concentrations } \\
\text { (Bq/kg-wet) }\end{array}$ & $\begin{array}{l}\text { Concentration ratios } \\
\text { between sea sediments } \\
\text { and benthic organisms }\end{array}$ \\
\hline \multirow{2}{*}{ Polychaeta } & Glyceridae & N.D. $(<2.89)$ & - \\
\cline { 2 - 4 } & Eunicidae & 11.2 & 0.0519 \\
\cline { 2 - 4 } & Flabelligeridae & 99.4 & 0.460 \\
\cline { 2 - 4 } & Terebellidae & 30.2 & 0.140 \\
\cline { 2 - 4 } & Opheliidae & N.D. $(<6.56)$ & - \\
\cline { 2 - 4 } & Polynoidae & 12.1 & 0.0560 \\
\hline \multirow{3}{*}{ Crustacea } & Crangonidae & 1.09 & 0.00505 \\
\cline { 2 - 4 } & Paradorippe granulata & 4.37 & 0.0202 \\
\hline \multirow{2}{*}{ Asteroidea } & Philyra syndactyla & 3.58 & 0.0166 \\
\cline { 2 - 4 } & Luidia quinaria & 2.65 & 0.0123 \\
\cline { 2 - 4 } & Asterias amurensis & N.D. $(<2.47)$ & - \\
\hline
\end{tabular}

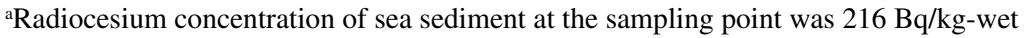


around their body. Ono et al. (in press, 2015) reported that organic matter in marine sediments had a higher radiocesium concentration than did mineral substances. Therefore, it is thought that the feeding habitats of benthic organisms influence radiocesium concentrations within the organisms. In this investigation, we observed internal sediments in the Flabelligeridae specimens, which had the highest radiocesium concentration. Species belonging to Flabelligeridae, Terebellidae, and Opheliidae are categorized as filter feeders or surface deposit feeders (Fauchald and Jumars 1979). Except for the Opheliidae specimens, radiocesium concentrations in deposit feeder polychaetes were comparatively higher than in other benthic organisms. In contrast, species with low radiocesium concentration (Glyceridae, Eunicidae, and Polynoidae) are categorized as carnivore or herbivore feeders. The reason for low contamination levels in Opheliidae specimens was unclear. Additional and continuous investigations are required to reveal the relationship between radiocesium contamination and feeding habitats of benthic organisms off the coast of Fukushima.

\subsection{Rearing Experiments of the Marine Polychaete (Perinereis aibuhitensis) Using Highly Contaminated Sediment from Near the FNPP}

Contaminated sediments from near the FNPP $\left(37^{\circ} 24.850^{\prime} \mathrm{N}-141^{\circ} 02.330^{\prime} \mathrm{E}\right)$ were collected using a Smith-Mclntyre grab sampler on the R/V Takusui of the Fukushima Prefectural Fisheries Experimental Station in August 2013. After removing impurity particles using a 2-mm sieve, we agitated the contaminated sediment for equalization. Before initiating the rearing experiments, we confirmed noncontamination of the marine polychaete (Perinereis aibuhitensis) specimens with an HPGe semiconductor detector. The specimens of $P$. aibuhitensis were reared for 5 weeks in four tanks $(450 \mathrm{~mm} \times 300 \mathrm{~mm} \times 330 \mathrm{~mm})$ with the contaminated sediments, and then $P$. aibuhitensis were reared for 2 weeks without sediments (seawater only). The ${ }^{137} \mathrm{Cs}$ concentrations of living $P$. aibuhitensis in plastic cylindrical containers were measured with an HPGe semiconductor detector, and then the specimens were returned to the rearing tank. The sediment samples were dried at $60{ }^{\circ} \mathrm{C}$ for 7 days, and the dry weight was converted into wet weight concentrations using the percentage of lost water content. Because organic matter in contaminated sediments has a high preference for radiocesium (Ono et al. in press, 2015), an ignition loss test was employed to determine the sediment content in each of the four tanks. The sediment samples were heated in a muffle furnace at $750{ }^{\circ} \mathrm{C}$ for $1 \mathrm{~h}$.

Figure 7.3 shows the time-series trends of ${ }^{137} \mathrm{Cs}$ concentrations for contaminated sediments and $P$. aibuhitensis in each tank. At the start of the rearing experiment, the ${ }^{137} \mathrm{Cs}$ concentration in the contaminated sediments was $1,250 \mathrm{~Bq} / \mathrm{kg}$-wet. However,

${ }^{137} \mathrm{Cs}$ concentrations in the contaminated sediments fluctuated with time. During the rearing period with contaminated sediments, the geometric mean of ${ }^{137} \mathrm{Cs}$ concentration for sediments in tank 1, tank 2, tank 3, and tank 4 were 1,500 Bq/kg-wet, 


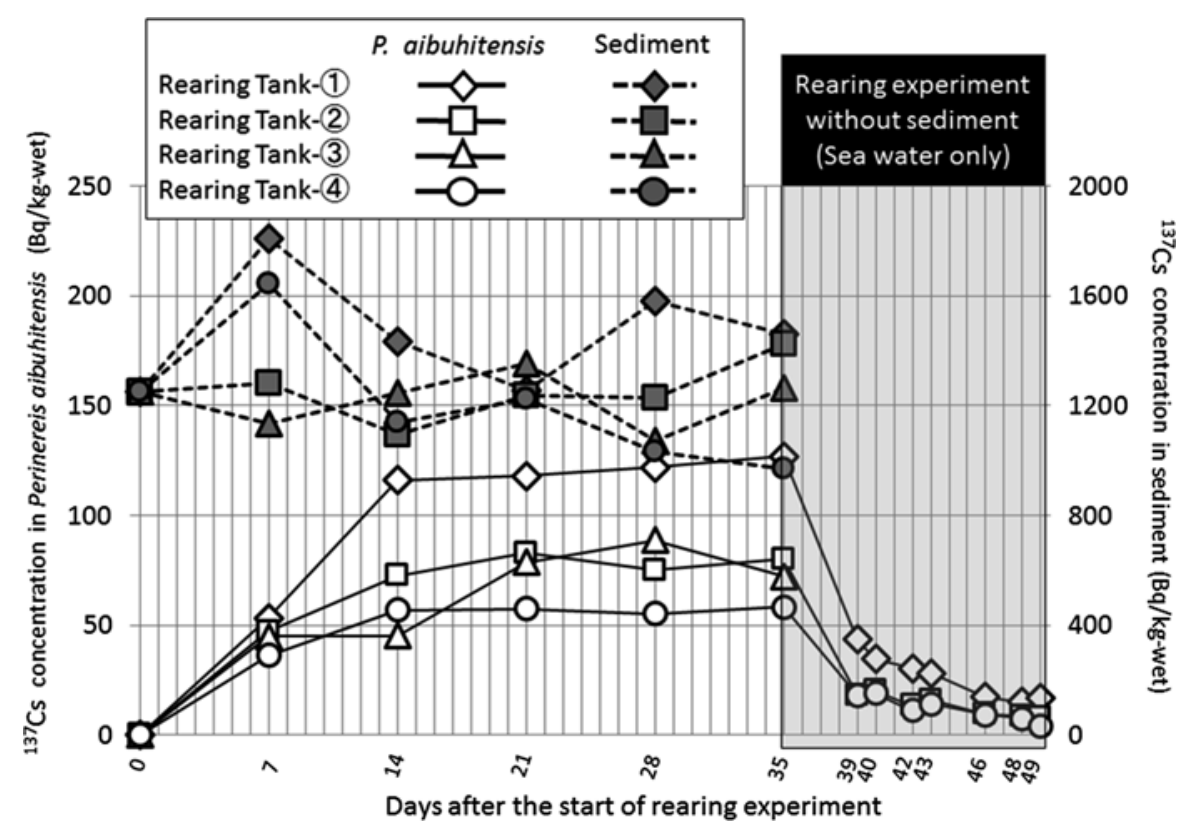

Fig. 7.3 Temporal trends of ${ }^{137} \mathrm{Cs}$ concentrations in Perinereis aibuhitensis and sediments

Table 7.2 Temporal trend of organic matter contents (\%) in sediments for each rearing tank

\begin{tabular}{l|l|l|l|l|l|l|l}
\hline \multirow{2}{*}{ Tank } & & \multicolumn{5}{|l}{ Days after the start of rearing experiment } \\
\cline { 4 - 7 } & & 7 days & 14 days & 21 days & 28 days & 35 days \\
\hline Rearing tank-(1) & Initial value 5.9 & 5.1 & 5.1 & 4.9 & 4.5 & 5.1 \\
\hline Rearing tank-(2) & & 4.2 & 4.8 & 4.7 & 4.6 & 4.5 \\
\hline Rearing tank-(3) & & 5.3 & 5.4 & 5.8 & 4.4 & 4.3 \\
\hline Rearing tank-(4) & & 4.9 & 4.7 & 5.5 & 4.4 & 4.9 \\
\hline
\end{tabular}

$1,250 \mathrm{~Bq} / \mathrm{kg}$-wet, $1,210 \mathrm{~Bq} / \mathrm{kg}$-we,t and 1,180 Bq/kg-wet, respectively. Insufficient agitation of the initial contaminated sediments and the burrowing activity of $P$. aibuhitensis could have caused the variation of ${ }^{137} \mathrm{Cs}$ concentration among the tanks. In contrast, the organic matter content in the contaminated sediments for each tank was approximately equal during the rearing period (Table 7.2).

The ${ }^{137} \mathrm{Cs}$ concentrations of $P$. aibuhitensis reached the maximum value after approximately 2 weeks, and conspicuous fluctuations were not observed during the next 3 weeks. On the 35th day after the start of the experiment, the $\mathrm{CR}$ for ${ }^{137} \mathrm{Cs}$ between $P$. aibuhitensis and sediments (wet/wet) was less than 0.10 (tank $1=0.087$, $\operatorname{tank} 2=0.056$, tank $3=0.057$, tank $4=0.060$ ). Meanwhile, the ${ }^{137} \mathrm{Cs}$ concentrations in P. aibuhitensis varied among the tanks. On the 14th day after the start of the experiment, the ${ }^{137} \mathrm{Cs}$ concentrations in tank 1, tank 2, tank 3, and tank 4 were $116 \mathrm{~Bq} / \mathrm{kg}$-wet, $72.5 \mathrm{~Bq} / \mathrm{kg}$-wet, $45.1 \mathrm{~Bq} / \mathrm{kg}$-wet, and $56.8 \mathrm{~Bq} / \mathrm{kg}$-wet, respectively. Four days after separation from the contaminated sediments, the ${ }^{137} \mathrm{Cs}$ concentration 
in $P$. aibuhitensis rapidly decreased, to $23-34 \%$ of the concentration on the 35 th day. The ${ }^{137} \mathrm{Cs}$ concentration in $P$. aibuhitensis eventually decreased to less than $20 \mathrm{~Bq} / \mathrm{kg}$-wet in all tanks. These results suggest that the ${ }^{137} \mathrm{Cs}$ concentrations in $P$. aibuhitensis are associated with the sediment contamination level in each tank. We assumed that the observed radiocesium concentration in $P$. aibuhitensis include measurements of contaminated sediments in their digestive systems.

Our rearing experiments determined that the $\mathrm{CR}$ for radiocesium between $P$. aibuhitensis and contaminated sediments (wet/wet) was less than 0.10 . Otosaka and Kobayashi (2013) calculated that the amount of bioavailable ${ }^{137} \mathrm{Cs}$ in the surface sediment layer $(0-3 \mathrm{~cm})$ off the coast of Ibaraki Prefecture (approximately $70 \mathrm{~km}$ south of the FNPP) was only about $20 \%$ of the total sedimentary ${ }^{137}$ Cs because more than $75 \%$ of the ${ }^{137} \mathrm{Cs}$ was incorporated into lithogenic fractions that were not bioavailable to marine products. Therefore, most of the sedimentary radiocesium in the digestive system of benthic organisms would be excreted with their wastes. Moreover, the ability of osmoconformation in invertebrates would influence the rapid excretion of internally absorbed radiocesium. The results of our study indicate that the intake of radiocesium through the benthic food web is limited for benthic organisms and demersal fish species, despite high contamination of the surrounding sediments.

Acknowledgments We are grateful to Satoshi Igarashi for the sorting of benthic organisms. We also thank Takami Morita and Ken Fujimoto for their valuable discussions and information. We appreciate the captains and crews of the R/V Takusui and Taka-maru for sampling contaminated sediments and benthic organisms.

Open Access This chapter is distributed under the terms of the Creative Commons Attribution Noncommercial License, which permits any noncommercial use, distribution, and reproduction in any medium, provided the original author(s) and source are credited.

\section{References}

Ambe D, Kaeriyama H, Shigenobu Y, Fujimoto K, Ono T, Sawada H, Saito H, Miki S, Setou T, Morita T, Watanabe T (2014) Five-minute resolved spatial distribution of radiocesium in sea sediment derived from the Fukushima Dai-ichi Nuclear Power Plant. J Environ Radioact 138:264-275

Buesseler KO (2012) Fishing for answers off Fukushima. Science 338:480-482

Fauchald K, Jumars PA (1979) The diet of worms: a study of polychaete feeding guilds. Oceanogr Mar Biol Annu Rev 17:193-284

Ono T, Ambe D, Kaeriyama H, Shigenobu Y, Fujimoto K, Sogame K, Nishiura N, Fujikawa T, Morita T, Watanabe T (2015) Concentration of ${ }^{134} \mathrm{Cs}+{ }^{137} \mathrm{Cs}$ bonded to the organic fraction of sediments offshore Fukushima, Japan. Geochem J 49 (in press)

Otosaka S, Kobayashi T (2013) Sedimentation and remobilization of radiocesium in the coastal area of Ibaraki, $70 \mathrm{~km}$ south of the Fukushima Dai-ichi Nuclear Power Plant. Environ Monit Assess 185:5419-5433 
Sohtome T, Wada T, Mizuno T, Nemoto Y, Igarashi S, Nishimune A, Aono T, Ito Y, Kanda J, Ishimaru T (2014) Radiological impact of TEPCO's Fukushima Dai-ichi Nuclear Power Plant accident on invertebrates in the coastal benthic food web. J Environ Radioact 138:106-115

Tateda Y, Tsumune D, Tsubono T (2013) Simulation of radioactive cesium transfer in the southern Fukushima coastal biota using a dynamic food chain transfer model. J Environ Radioact $124: 1-12$

Thornton B, Ohnishi S, Ura T, Odano N, Sasaki S, Fujita T, Watanabe T, Nakata K, Ono T, Ambe D (2013) Distribution of local ${ }^{137} \mathrm{Cs}$ anomalies on the seafloor near the Fukushima Dai-ichi Nuclear Power Plant. Mar Pollut Bull 74:344-350

Tsumune D, Tsubono T, Aoyama M, Hirose K (2012) Distribution of oceanic ${ }^{137} \mathrm{Cs}$ from the Fukushima Dai-ichi nuclear power plant simulated numerically by a regional ocean model. J Environ Radioact 111:100-108

Ueda T, Nakamura R, Suzuki Y (1977) Comparison of influence of sediments and sea water on accumulation of radionuclides by worms. J Radiat Res 18:84-92

Wada T, Nemoto Y, Shimamura S, Fujita T, Mizuno T, Sohtome T, Kamiyama K, Morita T, Igarashi S (2013) Effects of the nuclear disaster on marine products in Fukushima. J Environ Radioact 124:246-254 